\title{
Chitosan-Tripolyphosphate Nanoparticles of Mango Ginger (Curcuma mangga) Extract: Phytochemical Screening, Formulation, Characterization, and Antioxidant Activity
}

\author{
Bayyinatul Muchtaromah',*, Didik Wahyudi', Mujahidin Ahmad', Arif Nur Muhammad Ansori², Rahmi \\ Annisa $^{3}$, Lil Hanifah ${ }^{1}$
}

Bayyinatul Muchtaromah ${ }^{1, *}$, Didik Wahyudi', Mujahidin Ahmad', Arif Nur Muhammad Ansori², Rahmi Annisa ${ }^{3}$, Lil Hanifah ${ }^{1}$

'Department of Biology, Faculty of Science and Technology, Maulana Malik Ibrahim State Islamic University, Malang, INDONESIA. ${ }^{2}$ Doctoral Program in Veterinary Science, Faculty of Veterinary Medicine, Universitas Airlangga, Surabaya, INDONESIA.

${ }^{3}$ Department of Pharmacy, Faculty of Medical and Health Sciences, Maulana Malik Ibrahim State Islamic University, Malang, INDONESIA.

\section{Correspondence}

Bayyinatul Muchtaromah

Department of Biology, Faculty of Science and Technology, Maulana Malik Ibrahim State Islamic University, Malang, INDONESIA

E-mail: bayyinatul@bio.uin-malang.ac.id History

- Submission Date: 18-04-2021;

- Review completed: 12-06-2021;

- Accepted Date: 18-06-2021.

DOI : 10.5530/pj.2021.13.138

Article Available online

http://www.phcogj.com/v13/i5

Copyright

(C) 2021 Phcogj.Com. This is an openaccess article distributed under the terms of the Creative Commons Attribution 4.0 International license.

\begin{abstract}
Introduction: Mango ginger (Curcuma mangga) is one of Indonesia's medicinal plants widely used in most communities as a lust booster and for detoxifying purposes. Therefore, the purpose of this study is to synthesize chitosan-tripolyphosphate nanoparticles from mango ginger extract, determine their chemical contents, the nano chitosan characteristics, and its antioxidant activity. Methods: In this study, we macerated mango ginger using $70 \%$ ethanol solvent, then performed phytochemical test and formulation of chitosan nanoparticles of mango ginger extract. The group of secondary metabolites that showed positive results with the reagent test was further identified through TLC. Results: The results showed that the extract contained flavonoids and triterpenoids. Also, characterization of chitosan nanoparticles from the extract was conducted with FTIR test, PSA, XRD, and SEM. Based on the results, the nano chitosan particle size was $993 \mathrm{~nm}$ and examination with FTIR showed the presence of $\mathrm{N}-\mathrm{H}$ and $\mathrm{P}=\mathrm{O}$ groups, indicating ammonium ion interaction from chitosan with the polyanion from TPP and Mango ginger. Additionally, the XRD results showed that the crystals formed were in an amorphous form, which was supported by particle morphology images from SEM. Furthermore, the nanoparticles showed very strong antioxidant activity based on the reaction with DPPH. Conclusion: Based on these results, the phytochemical identification of mango ginger extract showed positive results in flavonoid and triterpenoid compounds. In addition, based on the characterization of the nanoparticles, the mango ginger extract showed positive results, illustrating that the nano chitosan synthesis was successful. Furthermore, the nano chitosan has a very strong antioxidant activity with an $\mathrm{IC}_{50}$ value of $18.08 \mu \mathrm{g} / \mathrm{mL}$.

Key words: Chemical identification, Nanoparticles, Chitosan, Mango ginger, TPP.
\end{abstract}

\section{INTRODUCTION}

The use of plants for medicinal purposes is common in Indonesia. ${ }^{1,2}$ A medicinal plant widely used in various communities is the mango ginger (Curcuma mangga). ${ }^{3}$ This is used as a lust booster and detoxification drug. Preliminary studies in identifying the group of compounds in its extracts showed some pharmacological effects, making it important in pharmaceutical industries. ${ }^{4}$

The separation of secondary metabolite compounds such as alkaloids, flavonoids, triterpenoids, steroids, saponins, and tannins from this plant is carried out through TLC methods. This research is a preliminary screening to determine the profile of mango ginger extracts as a basis for making the right drug delivery system. Compounds with low solubility in water also have low bioavailability in the body. This could be prevented by developing mango ginger extract nanoparticles using ionic gelation methods by chitosan polycation. Nanoparticles are materials with particle size on the nanometer scale, and the application of nanotechnology is common in the health and pharmaceutical world, used in drug delivery and is not harmful to the human body. ${ }^{5}$

Chitosan is a non-toxic natural polysaccharide, which is biodegradable. It has a cellulose-like structure with the ability to form a gel in an acidic atmosphere, and matrix-like in drug delivery systems. ${ }^{6}$ One of the methods used for synthesizing chitosan nanoparticles is the ionic gelation method. ${ }^{7}$ Most researchers make use of this method due to its simple process, and the particles released are easily controlled. The principle of nanoparticles formation in this method is based on the occurrence of electrostatic interactions between amine groups in positively charged chitosan with negatively charged polyanion TPP to form a three-dimensional intramolecular structure. ${ }^{8}$ This study involves the phytochemical identification of chitosan-TPP nanoparticles synthesized from mango ginger extract, determination of its characteristics, as well as its antioxidant activity.

\section{MATERIALS AND METHODS}

\section{Materials}

Mango ginger revealed from Balai Materia Medika, Batu, Indonesia. 70\% ethanol (Bratachem), chitosan (Himedia), tripolyphosphate (Sigma Aldrich), and acetic acid (Merck).

\section{Extraction of mango ginger extract}

Mango ginger was macerated using $70 \%$ ethanol solvent. The mixture was soaked for 24 hours, then filtered. Maceration was repeated three times to obtain a clear colored filtrate. The filtrate obtained was concentrated with a rotary evaporator at $50{ }^{\circ} \mathrm{C}$. 


\section{Phytochemical test with reagent test}

Phytochemical tests were carried out on the active compounds of the ethanol extract dissolved in a little solvent. Compounds tested with the reagent include; alkaloid, flavonoid, triterpenoid, steroid, saponin, and tannin.

\section{Separation of active compounds with TLC}

The group of secondary metabolites that showed positive results with the reagent test was further identified through TLC. The $\mathrm{GF}_{254}$ silica gel plate was used in the chromatography, and the Spots formed on it were at a wavelength between 254 and $366 \mathrm{~nm}$. These were further sprayed with Spot's viewer and then viewed under the same UV light. Characteristics observed in the Spot include; the number, color, and distance of migration from its original place, i.e., the $\mathrm{Rf}$ value.

\section{Formulation of chitosan nanoparticles from mango ginger extract}

The ionic gelation method was used with sonification time of 90 minutes. This involved dissolving 0.1 gram of mango ginger extract in $5 \mathrm{ml}$ of $70 \%$ ethanol. Then, $0.5,0.75$, and $1 \%$ of chitosan solution were separately put into $100 \mathrm{ml}$ of acetic acid and stirred until it dissolved. Also, $0.1,0.15$, and 0.2 gram of TPP were dissolved in 20, 30, and 40 $\mathrm{ml}$ of distilled water, respectively. Then, $1 \mathrm{ml}$ of tween 80 was added to each solution concentration and stirred using a homogenizer at speed of $1000 \mathrm{rpm}$ for 10 minutes. This mixture of chitosan, TPP, and mango ginger extract was turned into homogeneous using a disperser at speed of $3000 \mathrm{rpm}$ for 30 minutes. The mixture was then left for 24 hours and lyophilized (freeze-drying) to obtain nanoparticles in the form of powder samples. ${ }^{9}$

\section{Characterization of chitosan nanoparticles in mango ginger extract}

The particle size measurement and distribution were carried out using the Nanotrac Wave II Q by Microtrac MRB. Results were calculated from the average fluctuations in the light scattering intensity.

\section{Functional group examination}

This was conducted using FTIR. The mixture was kept in a vacuum freeze dryer for one day, and the resulting powder was irradiated with infrared light at a wavelength of $4000-400 \mathrm{~cm}^{-1}$.

\section{Crystal formation examination}

This was conducted using XRD, and the level of crystallinity was determined using wavelength source of $1.5406^{\circ} \mathrm{A} .{ }^{9}$

\section{Particle morphology examination}

The particle morphology examination was carried out with a SEM at magnification of $500 \times .5,9$

\section{RESULTS AND DISCUSSION}

The extraction process with 101.300 grams of mango ginger powder produced a thick extract of 19.657 grams (yield of $19.405 \%$ ) (Table 1). The phytochemical test provided an overview of the secondary metabolite compounds contained in each extract. This was performed on alkaloids, flavonoids, triterpenoids, steroids, saponins, and tannins groups (Table 2). The results of phytochemical testing were strengthened with the separation of active compounds, flavonoids, and triterpenoids, through TLC. The separation results of flavonoid from mango ginger ethanol extract in 5 eluent variations are presented below (Table 3). The best eluent for flavonoid separation in the mango ginger extract was methanol:chloroform (1:9), which produced orange Spots and turned green after being evaporated with ammonia, and two other green Spots before and after being steamed with ammonia with $\mathrm{Rf}$ of $0.813,0.9$, and 0.95 respectively. Similarly, the results of triterpenoid separation from mango ginger extract using seven eluent variations are shown below (Table 4). The best eluent for triterpenoid separation in mango ginger extract is $n$-hexane: ethyl acetate (6:4), which produced 6 Spots; purple (0.188), orange (0.356), green (0.275), (0.325), (0.85) and yellow (0.906). The Spots were clear, and the separation was good.

Table 1: The Result of Mango Ginger Extract through the Maceration Method.

\begin{tabular}{|lccccc}
\hline Extract & $\begin{array}{c}\text { Sample Weight } \\
\text { Solvent }\end{array}$ & $\begin{array}{c}\text { Filtrate Color } \\
\text { Change }\end{array}$ & Solid Extract Color & Extract Weight & Yield \\
\hline Mango Ginger & $101.3 \mathrm{~g}+1000 \mathrm{~mL}$ & Solid black to pale black & Black & $19.657 \mathrm{~g}$ & $19.405 \%$ \\
\hline
\end{tabular}

Table 2: Results of Phytochemical Test of Mango Ginger Extract.

\begin{tabular}{|ccc|}
\hline Compound group & Reagents & Test Results \\
\hline Alkaloids & Dragendorff & - \\
Flavonoids & Mayer & + \\
Triterpenoid & Wilstater & + \\
Steroids & Lieberman-Burchard & - \\
Saponin & Lieberman-Burchard & - \\
Tannin & Forth & - \\
\hline
\end{tabular}

Note:

+: positive towards compounds/color is formed.

-: negative towards compounds/no color.

Table 3: Analytical TLC Rf Value of Flavonoid in Mango Ginger Extract.

\begin{tabular}{lccc}
\hline \multirow{2}{*}{ Eluent } & \multicolumn{3}{c}{ Rf Value } \\
\cline { 2 - 4 } Butanol:Acetic Acid:Water (3:1:1) & Spot 1 & Spot 2 & Spot 3 \\
Butanol:Acetic Acid:Water (3:1:1) & - & 0.938 & - \\
Methanol:Chloroform (1:39) & 0.125 & 0.225 & - \\
Chloroform:Methanol:Water (9.7:0.2:0.1) & 0.125 & 0.225 & - \\
Methanol:Chloroform (1:9) & 0.088 & 0.125 & 0.375 \\
\hline
\end{tabular}


Muchtaromah B, et al: Chitosan-Tripolyphosphate Nanoparticles of Mango Ginger (Curcuma mangga) Extract: Phytochemical Screening, Formulation, Characterization, and Antioxidant Activity

Table 4: Analytical TLC Rf Value of Triterpenoid in Mango Ginger Extract.

\begin{tabular}{|c|c|c|c|c|c|c|}
\hline \multirow{2}{*}{ Eluent } & \multicolumn{6}{|c|}{ Rf value } \\
\hline & Spot 1 & Spot 2 & Spot 3 & Spot 4 & Spot 5 & Spot 6 \\
\hline n-Hexane:Ethyl acetate $(2: 8)$ & 0.775 & 0.831 & 0.8875 & 0.925 & - & - \\
\hline n-Hexane:Ethyl acetate $(8: 2)$ & 0.056 & 0.081 & - & - & - & - \\
\hline n-Hexane:Ethyl acetate (6:4) & 0.188 & 0.356 & 0.275 & 0.325 & 0.850 & 0.906 \\
\hline n-Hexane:Acetone (80:20) & 0.012 & 0.937 & - & - & - & - \\
\hline
\end{tabular}

Table 5: The IC 50 value on the Mango Ginger Extract Nanoparticles, Mango Ginger Extract, and Ascorbic Acid.

\begin{tabular}{cc}
\hline Antioxidant Testing & $\mathrm{IC}_{50}(\mu \mathrm{g} / \mathrm{mL})$ \\
\hline Mango Ginger Extract Nanoparticles & 18.08 \\
Mango Ginger Extract & 16.18 \\
Ascorbic Acid & 14.81
\end{tabular}

This was carried out using the ionic gelation method, which involved a reaction between the mixture of chitosan and TPP which was used as a stabilizer. Also, the TPP added acted as a crosslinking agent, strengthening the chitosan nanoparticle matrix, hence, producing stable chitosan nanoparticles. Additionally, surfactant (tween 80) was added, which also functioned as a stabilizer. The surfactant, in addition, helped the chitosan particles in the solution to come together and stabilize with one another, thus, forming effective nanoparticles that are smaller in size. Mainly, the use of TPP was to avoid the formation of aggregates and as a stabilizer of the formed nanoparticles. ${ }^{10,11}$

The success in transforming a sample into nanoparticles is known by measuring the sample size. Results obtained showed an average particle size of $993 \mathrm{~nm}$, indicating a nanometer particle size. Therefore, chitosan nanoparticles can increase the bioavailability of active compounds in the body. Particle measurement results are presented below (Figure 1).

The FTIR instrument was used to identify the complex groups in the compounds but was unable to determine their constituent elements. With FTIR, infrared radiation passes through the sample, and while some of the radiation is absorbed, some are transmitted by the sample. In general, the molecule absorbs the radiation if the frequency of its vibration is equal to the infrared radiation frequency, which is directed towards it. The results of the functional group's examination on chitosan nanoparticles from mango ginger extract are shown below (Figure 2).

Figure 2 shows its chemical profile in the form of different spectrum patterns with distinctive characteristics. Chitosan has specific groups, such as $-\mathrm{NH}_{2}$ and $-\mathrm{OH} .{ }^{12}$ The FTIR results showed the presence of hydroxyl groups at wavelength of $3425.56 \mathrm{~cm}^{-1}$ due to the vibrational strain interaction between the hydroxyl group and the amide group on chitosan. However, the chitosan amide function group was at a wavelength of $1640.56 \mathrm{~cm}^{-1}$. The FTIR results showed the functional groups in chitosan from mango ginger extract nanoparticle within 90 minutes of sonication period. Determination of chitosan presence is needed to determine the extract coating ability, and a method used to determine its presence is through FTIR. The infrared spectrum has the ability to detect functional groups and identify compounds in a polymer sample. ${ }^{13}$ The FTIR in this study used intermediate level wavenumbers, in the range of $4000-400 \mathrm{~cm}^{-1}$ and the determination of the wavelength value was in accordance with the functional groups in organic compounds. ${ }^{14}$ The working principle of FTIR is based on the absorption or transmission of infrared light by the molecules of compounds in the sample. The molecule absorbs the light if the frequency of its functional group's vibration is the same as the frequency of the infrared radiation. However, not all of the infrared light is absorbed by the molecule. ${ }^{15}$
The result obtained from FTIR is in the form of a transmittance graph.

Analysis of the crystal structure of the catalyst was conducted using $\mathrm{XRD}$. It is one of the oldest and most commonly used methods in material characterization to date. This XRD technique is used to identify a material based on its crystalline state by determining the lattice parameters and its particle size. The method is based on the fact that XRD patterns for each crystalline material have different characteristics. The result of the crystal formation examination is shown below (Figure 3).

The XRD analysis was used to determine the physical structure of the sample. The characterization results of the nanoparticles showed an amorphous property, indicating that the constituent particles were irregularly arranged and less compact. This irregular arrangement allows the easy insertion of other molecules. In addition, the more amorphous a molecule is, the easier it is to insert other molecules into it. ${ }^{16}$ Normally, the amorphous shape of a particle is marked by a valley peak at diffraction angle of $20^{\circ}$.

The SEM is a technique widely used for material characterization, with the capacity of viewing particle surface morphology up to $1 \mathrm{~nm}$ in size. ${ }^{17}$ It is also a method used to examine the shape and surface microstructure of an object which cannot be seen by the eye or with an optical microscope. ${ }^{18}$ Its large magnification range and the 3-dimensional image makes SEM results easier to observe and analyze. The results of this study showed that chitosan nanoparticles were mostly spherical. The result of the morphological examination of chitosan nanoparticles is presented below (Figure 4).

Analysis of antioxidant activity was carried out on mango ginger extract nanoparticles, mango ginger extract, and ascorbic acid used as control. Each of the samples were allowed to react with free radicals in the form of DPPH, and their absorbance was measured using a spectrophotometer. The absorbance measurement was carried out with test solution concentrations at $0,2,5,10$, and $25 \mathrm{ppm}$, measured from low to high concentration. The $\mathrm{IC}_{50}$ results are shown below (Table 5).

The table shows that the nanoparticles of mango ginger extract have an $\mathrm{IC}_{50}$ value of $18.08 \mu \mathrm{g} / \mathrm{mL}$, mango ginger extract has $16.18 \mu \mathrm{g} / \mathrm{mL}$ while ascorbic acid has $14.81 \mu \mathrm{g} / \mathrm{mL}$. These values in the three samples are indication that the antioxidant activities are very strong. The substance with an $\mathrm{IC}_{50}$ value of $\leq 50 \mu \mathrm{g} / \mathrm{mL}$, has a very strong antioxidant activity. However, values within 50-100 indicate a strong antioxidant activity, within 100-150 is classified as a weak, 150-250 is classified as weak, while $\geq 250$ is considered as inactive, but still has potential as an antioxidant substance. 


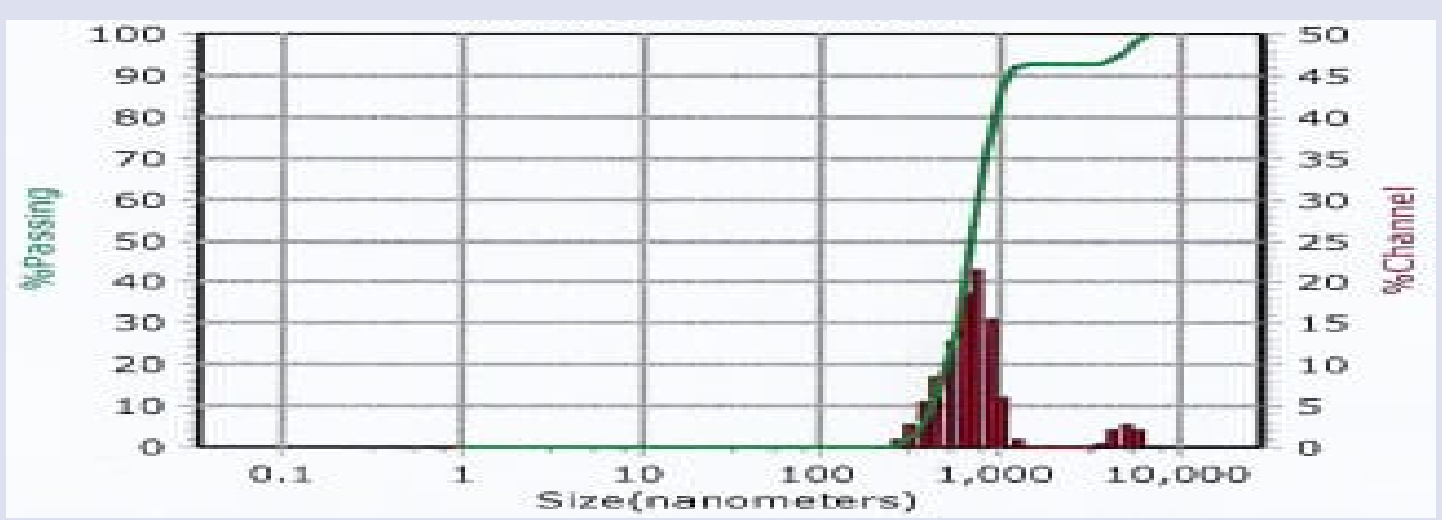

Figure 1: The size distribution of chitosan nanoparticles-mango ginger extract with sonication of 90 minutes using particle size analyzer.

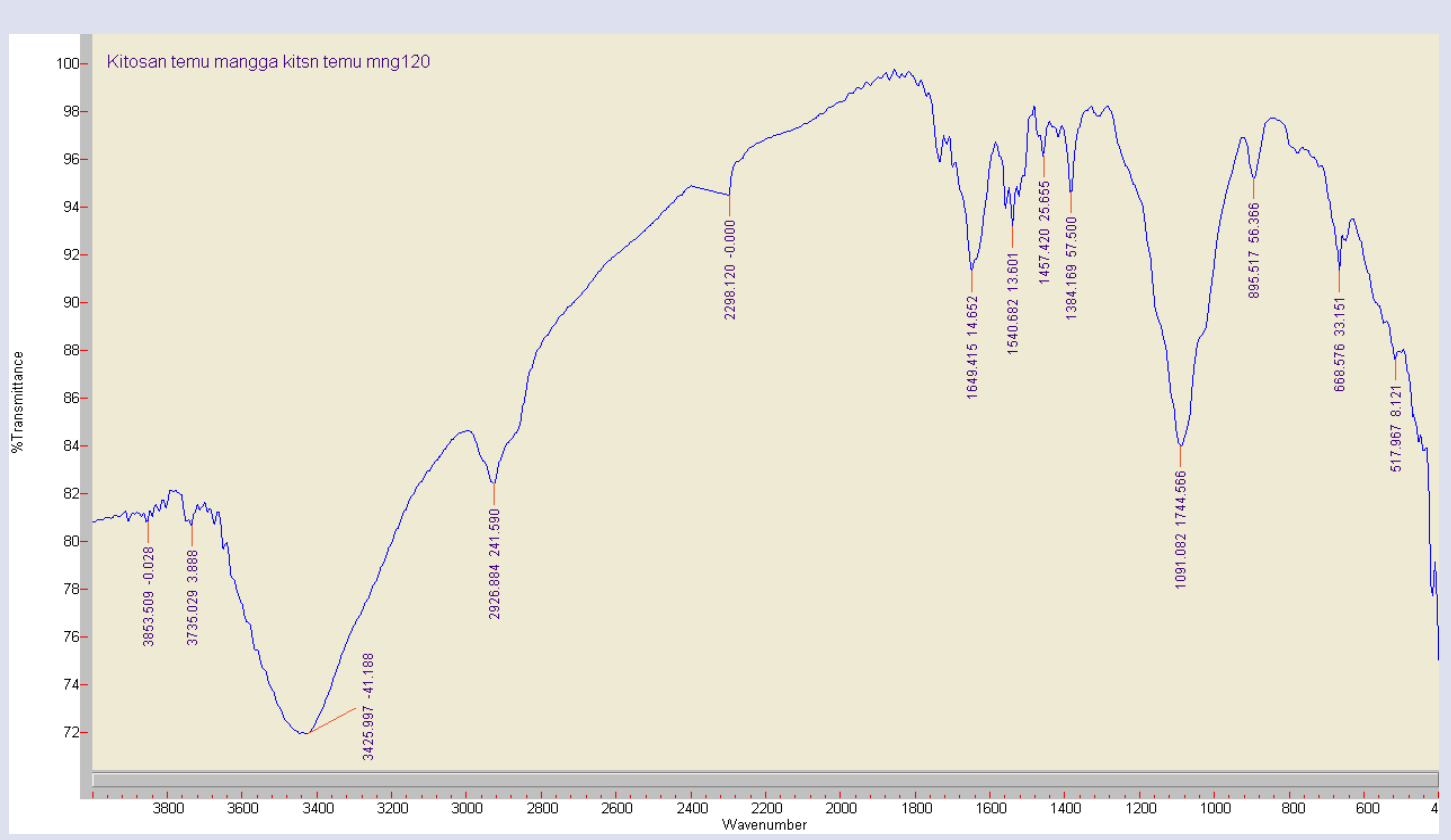

Figure 2: The results of functional groups examination on chitosan nanoparticles-mango ginger extract with sonication time of 90 minutes using FTIR.

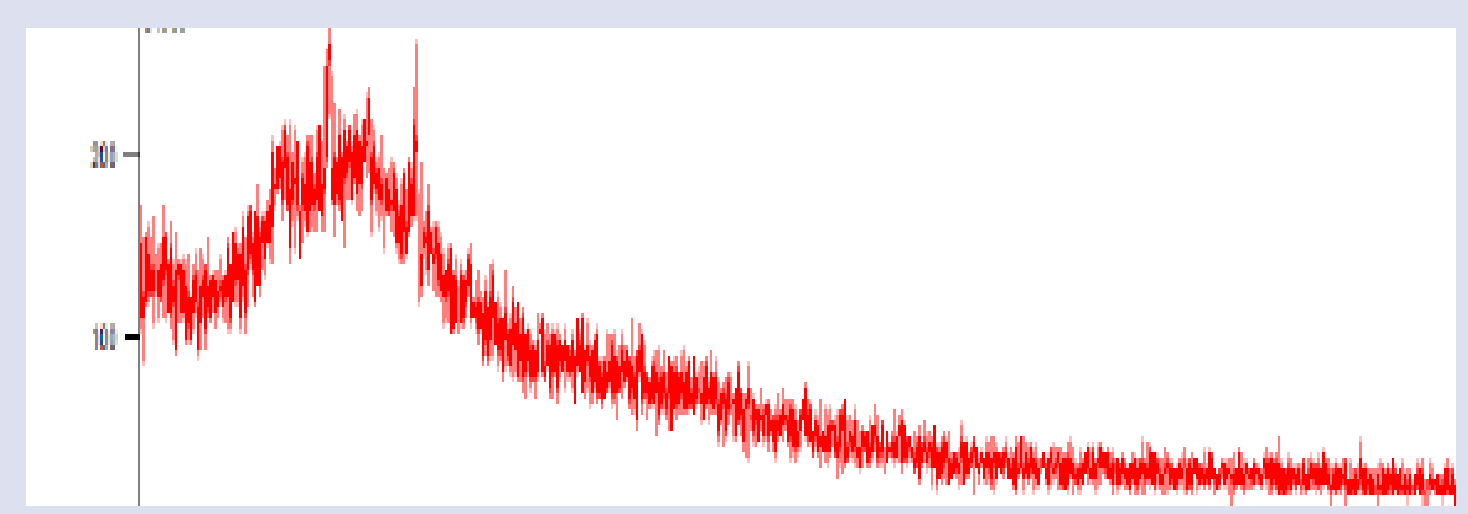

Figure 3: The results of the examination on chitosan nanoparticles crystals formation using XRD with sonication time of 90 minutes. 


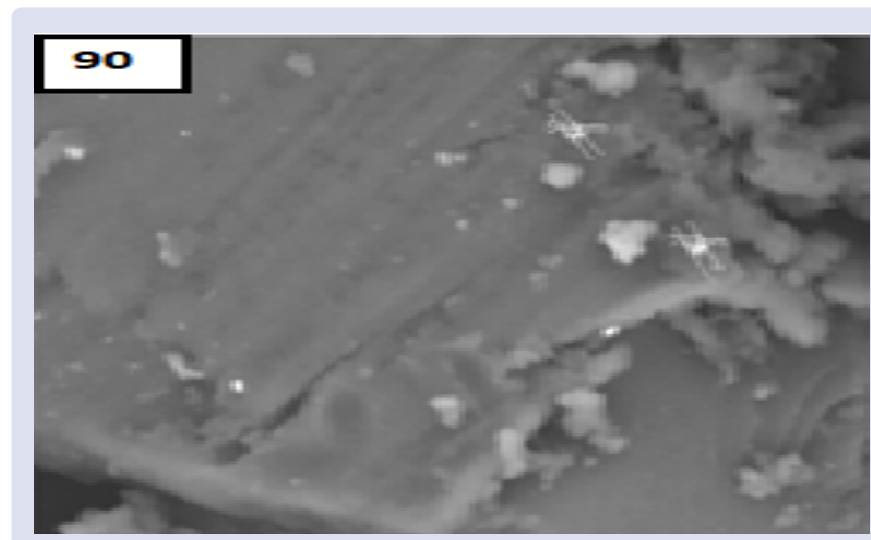

Figure 4: The results of morphological examination of chitosan nanoparticles with 90 minutes sonication using SEM.

\section{CONCLUSION}

Based on these results, the phytochemical identification of mango ginger extract showed positive results in flavonoid and triterpenoid compounds. In addition, based on the characterization of the nanoparticles, the mango ginger extract showed positive results, illustrating that the nano chitosan synthesis was successful. Furthermore, the nano chitosan has a very strong antioxidant activity with an $\mathrm{IC}_{50}$ value of $18.08 \mu \mathrm{g} / \mathrm{mL}$.

\section{ACKNOWLEDGMENT}

We thank EJA Team, Indonesia for editing the manuscript.

\section{DISCLOSURE STATEMENT}

The authors have no conflicts of interest to declare.

\section{ABBREVIATIONS}

DPPH: 2,2-diphenyl-1-picrylhydrazyl; FTIR: Fourier transform infrared spectroscopy; $\mathrm{IC}_{50}: 50 \%$ antiviral concentration; PSA: Particle size analyzer; Rf: Retardation factor; SEM: Scanning electron microscope; TLC: Thin layer chromatography; TPP: Tripolyphosphate; XRD: X-ray diffraction.

\section{REFERENCES}

1. Ansori ANM, Fadholly A, Proboningrat A, Jayanti S, Hayaza S, Susilo RJK, Sucipto TH, Soegijanto S. Efficacy of Allium cepa (Amaryllidaceae) extract against dengue virus type-2 (Flaviviridae: Flavivirus) isolated from Surabaya, Indonesia. Biochem Cell Arch. 2020; 20(2): 4783-4786.

2. Ansori ANM, Fadholly A, Proboningrat $A$, Antonius $Y$, Hayaza $S$, Susilo RJK, Inayatillah B, Sibero MT, Naw SW, Posa GAV, Sucipto TH, Soegijanto S. Novel antiviral investigation of Annona squamosa leaf extract against the dengue virus type-2: In vitro study. Pharmacog J. 2021; 13(2): 456-462.

3. Rahmadi A, Sabarina $Y$, Agustin S. Different drying temperatures modulate chemical and antioxidant properties of mandai cempedak (Artocarpus integer). F1000Res. 2018; 7: 1706.

4. Muchtaromah B, Ahmad M, Koestanti E, Ma'rifatul Y, Labone V. Phytochemicals, antioxidant and antifungal properties of Acorus calamus, Curcuma mangga, and Allium sativum. KnE Life Sci. 2017; 3(6): 93-104.
5. Fadholly A, Ansori ANM, Proboningrat A, Nugraha AP, Iskandar RPD, Rantam FA, Sudjarwo SA. Apoptosis of HeLa cells via caspase-3 expression induced by chitosan-based nanoparticles of Annona squamosa leaf extract: In vitro study. Indian J Pharm Educ Res. 2020; 54(2): 416-421.

6. Kimna C, Deger S, Tamburaci S, Tihminlioglu F. Chitosan/ montmorillonite composite nanospheres for sustained antibiotic delivery at post-implantation bone infection treatment. Biomed Mater. 2019; 14(4): 044101.

7. Ahmed TA, Aljaeid BM. Preparation, characterization, and potential application of chitosan, chitosan derivatives, and chitosan metal nanoparticles in pharmaceutical drug delivery. Drug Des Devel Ther. 2016; 10: 483-507.

8. Anitha A, Maya S, Deepa N, Chennazhi KP, Nair SV, Jayakumar R. Curcumin-loaded N,O-carboxymethyl chitosan nanoparticles for cancer drug delivery. J Biomater Sci Polym Ed. 2012; 23(11): 1381 400.

9. Li J, Tian S, Tao Q, Zhao Y, Gui R, Yang F, Zang L, Chen Y, Ping $Q$, Hou D. Montmorillonite/chitosan nanoparticles as a novel controlledrelease topical ophthalmic delivery system for the treatment of glaucoma. Int J Nanomedicine. 2018; 13: 3975-3987.

10. Nasti A, Zaki NM, de Leonardis $P$, Ungphaiboon $S$, Sansongsak $P$, Rimoli MG, Tirelli N. Chitosan/TPP and chitosan/TPP-hyaluronic acid nanoparticles: systematic optimisation of the preparative process and preliminary biological evaluation. Pharm Res. 2009; 26(8): 191830.

11. Mazzarino L, Travelet C, Ortega-Murillo S, Otsuka I, Pignot-Paintrand I, Lemos-Senna E, Borsali R. Elaboration of chitosan-coated nanoparticles loaded with curcumin for mucoadhesive applications. J Colloid Interface Sci. 2012; 370(1): 58-66.

12. Khalifa NS, Hasaneen MN. The effect of chitosan-PMAA-NPK nanofertilizer on Pisum sativum plants. 3 Biotech. 2018; 8(4): 193.

13. Kheiri A, Moosawi Jorf SA, Malihipour A, Saremi H, Nikkhah M. Synthesis and characterization of chitosan nanoparticles and their effect on Fusarium head blight and oxidative activity in wheat. Int $\mathrm{J}$ Biol Macromol. 2017; 102: 526-538.

14. Ghadi A, Mahjoub S, Tabandeh F, Talebnia F. Synthesis and optimization of chitosan nanoparticles: Potential applications in nanomedicine and biomedical engineering. Caspian J Intern Med. 2014; 5(3): 156-61.

15. Singh J, Dutta T, Kim KH, Rawat M, Samddar P, Kumar P. 'Green' synthesis of metals and their oxide nanoparticles: Applications for environmental remediation. J Nanobiotechnology. 2018; 16(1): 84.

16. Jahangirian $H$, Rafiee-Moghaddam $R$, Jahangirian $N$, Nikpey B, Jahangirian S, Bassous N, Saleh B, Kalantari K, Webster TJ. Green synthesis of zeolite/ $/ \mathrm{Fe}_{2} \mathrm{O}_{3}$ nanocomposites: Toxicity \& cell proliferation assays and application as a smart iron nanofertilizer. Int J Nanomedicine. 2020; 15: 1005-1020.

17. Maruyama CR, Guilger M, Pascoli M, Bileshy-José N, Abhilash PC Fraceto LF, de Lima R. Nanoparticles based on chitosan as carriers for the combined herbicides imazapic and imazapyr. Sci Rep. 2016; 6: 19768

18. Jones JR, Barrick C, Kim KA, Lindner J, Blondeau B, Fujimoto Y, Shiota M, Kesterson RA, Kahn BB, Magnuson MA. Deletion of PPARgamma in adipose tissues of mice protects against high fat diet-induced obesity and insulin resistance. Proc Natl Acad Sci U S A. 2005; 102(17): 6207-12. 


\section{GRAPHICAL ABSTRACT}

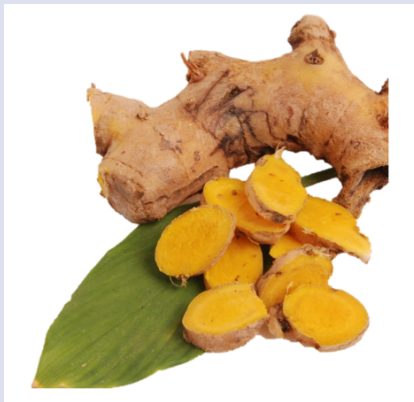

Curcuma mangga

\section{Phytochemical Test}

$(+)$ flavonoid

$(+)$ triterpenoid

\section{Formulation of Chitosan} Nanoparticles

$\mathrm{IC}_{50}$ value of $18.08 \mu \mathrm{g} / \mathrm{mL}$ (a strong antioxidant activity).

\section{ABOUT AUTHORS}

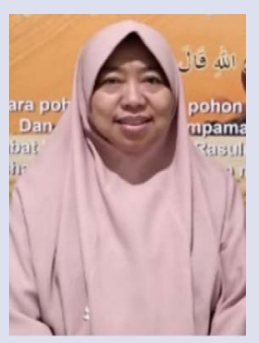

Bayyinatul Muchtaromah received her doctoral degree at Brawijaya University, Indonesia (2007). She is currently a lecturer at Biology Department of Universitas Islam Negeri (UIN) Maulana Malik Ibrahim Malang, Indonesia. Her research interest includes animal physiology and reproduction.

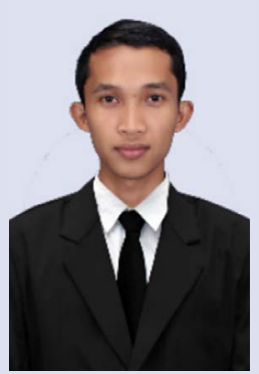

Didik Wahyudi received his master degree in Brawijaya University, Indonesia. He is a lecturer in Biology Department of Universitas Islam Negeri Maulana Malik Ibrahim Malang, Indonesia. His research interest includes botany, plant systematic and bioinformatics.

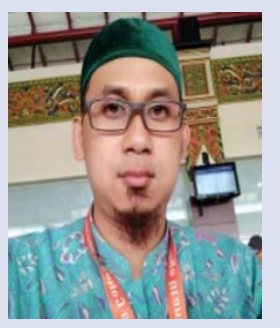

Mujahidin Ahmad received his master degree in Brawijaya University, Indonesia and King Mongkut's University of Technology Thonburi Bangkok. He is a lecturer in Biology department of Universitas Islam Negeri Maulana Malik Ibrahim Malang, Indonesia. His research interest includes biotechnology and animal systematic.

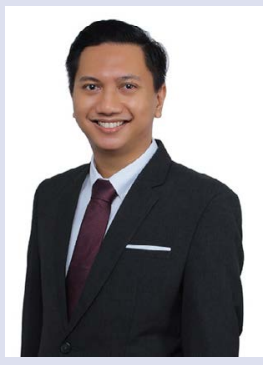

Arif Nur Muhammad Ansori is a Ph.D. candidate in Veterinary Science at Universitas Airlangga. He completed his B.Sc. in Biology and M.Sc. in Vaccinology and Immunotherapeutics at Universitas Airlangga. Currently, he is an awardee of PMDSU Scholarship (Batch III) at Universitas Airlangga. His research projects related to virology, bioinformatics, and molecular biology. His actual research focus is the application of molecular biology to the development of a novel bivalent vaccine against COVID-19. 
Rahmi Annisa received her master degree in Universitas Airlangga, Indonesia. She is currently a lecture in Pharmacy Department of Universitas Islam Negeri Maulana Malik Ibrahim Malang, Indonesia. Her research focused in drug delivery system.

Cite this article: Muchtaromah B, Wahyudi D, Ahmad M, Ansori ANM, Annisa R, Hanifah L. Chitosan-Tripolyphosphate Nanoparticles of Mango Ginger (Curcuma mangga) Extract: Phytochemical Screening, Formulation, Characterization, and Antioxidant Activity. Pharmacogn J. 2021;13(5): 1065-1071. 